\title{
Cephalometric norms for the upper airway of 12-year-old Chinese children
}

\author{
Min GU', Colman PJ McGrath², Ricky WK Wong ${ }^{3}$, Urban Hägg ${ }^{1}$ and Yanqi Yang ${ }^{1 *}$
}

\begin{abstract}
Objective: To establish cephalometric norms for the upper airway of 12-year-old Chinese children, and to assess these norms with regard to gender, age, ethnicity and other craniofacial structures.

Methods: Lateral cephalograms were obtained from a random sample of 425 12-year-old Chinese children (224 boys and 201 girls) to establish the Chinese norms, and from a matched group of 108 12-year-old Caucasian children (61 boys and 47 girls) as an ethnic comparison. Published data on the upper airway norms of Chinese adults were used to make age comparisons. Nine upper airway and 14 craniofacial variables were measured.

Results: Chinese boys tended to have a thicker soft palate $(P=0.008)$, and less depth in the retropalatal $(P=0.011)$, retroglossal $(P=0.034)$ and hypopharyngeal $(P<0.001)$ pharynx than Chinese girls, whereas no gender dimorphism was found in Caucasian children. Ethnic differences were found in the depth of the retroglossal oropharynx in both genders and the position of the hyoid bone in boys. Compared with Chinese adults, the overall size of the upper airway in Chinese children was smaller. The mandibular body length and the craniocervical inclination were found to be statistically significantly, albeit weakly correlated with upper airway variables.
\end{abstract}

Conclusions: Cephalometric norms for the upper airway of Chinese 12-year-old children were established, indicating gender-specific differences, and some ethnic differences were found in comparison with those of 12-year-old Caucasian children. An association between the mandibular body length and the craniocervical inclination with upper airway variables was also noticeable.

Keywords: Cephalometry, Chinese, Children, Upper airway

\section{Introduction}

Increasing evidence has shown an association between craniofacial anomalies and/or soft-tissue hypertrophy and pediatric sleep-disordered breathing (SDB) [1-3]. SDB represents a spectrum of breathing disorders during sleep that encompasses a continuum of diagnoses ranging from partial upper airway obstruction (primary snoring and upper airway resistance syndrome) to complete upper airway obstruction (obstructive hypoventilation and obstructive sleep apnea syndrome [OSAS]) [4]. In an updated clinical practice guideline on childhood OSAS from the American Academy of Pediatrics, SDB was defined simply as OSAS with additional snoring [5]. The

\footnotetext{
* Correspondence: yangyanq@hku.hk

'Orthodontics, Faculty of Dentistry, the University of Hong Kong, 34 Hospital Road, Hong Kong, SAR, China

Full list of author information is available at the end of the article
}

prevalence of children with OSAS ranges from 1 to 5\%, and the reported prevalence of habitual snoring varies widely from 1.5 to $27.6 \%$ [5]. If untreated, pediatric SDB may result in serious problems such as a failure to thrive, neurocognitive deficits, behavioral abnormalities and cardiovascular changes [6]. The common modalities of treatment for pediatric SDB include adenotonsillectomy, continuous positive airway pressure (CPAP), oral appliances and pharmacologic treatment [7].

The soft-tissue morphology of the upper airway that may related to pediatric SDB includes narrowed pharyngeal airways, and larger adenoids, tonsils and soft palates [8-10]; the related hard-tissue morphology includes an increased intermaxillary angle, a retrognathic mandible $[11,12]$, an increased mandibular angle, a longer lower anterior facial height [13,14], narrow dental arches and deep palatal height $[15,16]$, and an inferiorly positioned hyoid bone $[17,18]$.

\section{Biomed Central}

(c) 2014 GU et al.; licensee BioMed Central Ltd. This is an Open Access article distributed under the terms of the Creative Commons Attribution License (http://creativecommons.org/licenses/by/4.0), which permits unrestricted use, distribution, and reproduction in any medium, provided the original work is properly credited. The Creative Commons Public Domain Dedication waiver (http://creativecommons.org/publicdomain/zero/1.0/) applies to the data made available in this article, unless otherwise stated. 
Table 1 Demographic data of the study samples

\begin{tabular}{|c|c|c|c|c|c|c|}
\hline & \multirow[b]{2}{*}{$\mathrm{n}$} & \multicolumn{2}{|c|}{ Age range } & \multirow[b]{2}{*}{ Median } & \multicolumn{2}{|c|}{ Range } \\
\hline & & Mean & SD & & Minium & Maxium \\
\hline \multicolumn{7}{|c|}{ Chinese children } \\
\hline Male & 224 & 12.5 & 0.3 & 12.5 & 12.0 & 12.9 \\
\hline Female & 201 & 12.5 & 0.3 & 12.5 & 12.0 & 12.9 \\
\hline Difference $^{a}$ & & 0.0 & & & & \\
\hline \multicolumn{7}{|c|}{ Chinese adults } \\
\hline Male & 29 & - & - & - & 18.0 & 35.0 \\
\hline Feame & 45 & - & - & - & 16.0 & 42.0 \\
\hline Difference $^{b}$ & & - & & & & \\
\hline \multicolumn{7}{|l|}{ Caucasian } \\
\hline Male & 61 & 12.5 & 0.2 & 12.5 & 12.0 & 12.9 \\
\hline Female & 47 & 12.4 & 0.3 & 12.5 & 12.0 & 12.9 \\
\hline Difference $^{a}$ & & 0.1 & & & & \\
\hline
\end{tabular}

${ }^{a}$ None of the differences between the samples were statistically significant. ${ }^{b}$ Statistically significance could not be calculated.

Both upper airway and craniofacial structures can be observed in the same lateral cephalograms, and lateral cephalometric radiography was therefore considered to be a useful screening tool to assess upper airway structures, and identify subjects at risk of SDB $[19,20]$; its validity has been tested using three-dimensional computed tomography (CT) and magnetic resonance imaging (MRI) [21,22].

To assess the upper airway structures of individual patients from lateral cephalograms, reference norms are required. However, there is limited data on cephalometric norms of upper airway. McNamara [23] provided reference values for the upper pharynx and lower pharynx of Caucasian adults, whereas Samman et al. [24] presented cephalometric norms for the upper airway of Chinese adults. Until now, no cephalometric norms for upper airway of Chinese children has been established. Consequently, the objective of this retrospective study was to obtain upper airway norms for Chinese children, and study the association between airway dimensions and craniofacial structures.

\section{Materials and methods \\ Subjects}

The materials used were lateral cephalograms obtained from 12-year-old children during an oral health survey performed in 1984-85 at the Department of Orthodontics and Paediatric Dentistry of the University of Hong Kong [25]. In the survey, approximately 600 Chinese school children were selected by a partially stratified random sampling from 10 schools in Hong Kong, and approximately 100 Caucasian school children, whose parents originated from the United Kingdom, were chosen from two expatriate schools in Hong Kong [26]. Lateral cephalometric radiographs were taken as part of a comprehensive oral/dental/
Table 2 Cephalometric landmarks and measurements of the upper airway

\begin{tabular}{|c|c|}
\hline Variables & Definition \\
\hline \multicolumn{2}{|l|}{ Landmarks } \\
\hline Po & $\begin{array}{l}\text { Porion, the mid point of the line connecting the most } \\
\text { superior point of the external auditory canal on both sides }\end{array}$ \\
\hline Or & $\begin{array}{l}\text { Orbitale, the lowest point on the average of the left and } \\
\text { right inferior borders of the bony orbit }\end{array}$ \\
\hline ANS & $\begin{array}{l}\text { Anterior nasal spine, the tip of the median, sharp bony } \\
\text { process of the maxilla }\end{array}$ \\
\hline PM & $\begin{array}{l}\text { Pterygo-maxillare, the point at the junction fo the } \\
\text { pterygo-maxilla and the posterior nasal spine }\end{array}$ \\
\hline$U$ & Uvula, the tip of the uvula \\
\hline UPW & $\begin{array}{l}\text { Upper pharyngeal wall, point of intersection of the line } \\
\mathrm{NL} \text { to the posterior pharyngeal wall }\end{array}$ \\
\hline MPW & $\begin{array}{l}\text { Middle pharyngeal wall, intersection of the perpendicular } \\
\text { line from } U \text { to the posterior pharyngeal wall }\end{array}$ \\
\hline LPW & $\begin{array}{l}\text { Lower pharyngeal wall, intersection of the perpendicular } \\
\text { line from } V \text { to the posterior pharyngeal wall }\end{array}$ \\
\hline V & $\begin{array}{l}\text { Vallecula, the intersection of the epiglottis and the base } \\
\text { of the tongue }\end{array}$ \\
\hline $\mathrm{AH}$ & $\begin{array}{l}\text { Anterior hyoid, the most anterior and superior point on } \\
\text { the body of the hyoid bone }\end{array}$ \\
\hline C2 & $\begin{array}{l}\text { 2nd cervical vertebrae, the point at the most anterior-inferior } \\
\text { position on the second cervical vertebrae }\end{array}$ \\
\hline C3 & $\begin{array}{l}\text { 3rd cervical vertebrae, the point at the most anterior-inferior } \\
\text { position on the third cervical vertebrae }\end{array}$ \\
\hline $\mathrm{FH}$ & Frankort horizontal plane, line joining the Or to the Po \\
\hline $\mathrm{NL}$ & Nasal line, line joining the ANS and Pm \\
\hline CV & Cervical vertebrae, the line joining the $\mathrm{C} 2$ and $\mathrm{C} 3$ \\
\hline
\end{tabular}

Measurements

PM-U (mm) Length of soft palate, distance from PM to $U$

SPT (mm) Soft palate thickness, represents the maximal thickness of the soft palate measured perpendicular to PM-U line

NL/PM-U $\left(^{\circ}\right) \quad$ Inclincation of the long axis of the soft palate relative to the nasal line

PM-UPW Depth of the nasopharyngeal airway space from PM (mm) to UPW

U-MPW (mm) Depth of the oropharyngeal airway space from $U$ to MPW

PASmin $(\mathrm{mm})$ The shortest distance between the base of the tongue and the posterior pharyngeal wall, the narrowest sagittal airway space

V-LPW (mm) Depth of the hypopharyngeal airway space from $V$ to LPW

$\mathrm{AH}-\mathrm{FH}(\mathrm{mm})$ Position of the hyoid bone in vertical plane, from $\mathrm{AH}$ perpendicular to $\mathrm{FH}$

$\mathrm{AH}-\mathrm{CV}(\mathrm{mm}) \quad$ Position of the hyoid bone in horizontal plane, from $\mathrm{AH}$ to $\mathrm{CV}$ and parallel to $\mathrm{FH}$

facial examination. The lateral cephalograms used in this study were selected according to the following criteria: 1 , children aged 12.0 -13.0 years; 2 , who had not received or were not receiving ongoing orthodontic treatment; and 3, the upper airway structures were clear and no swallow action was detected in the cephalograms. After exclusions, 
lateral cephalograms from 224 male and 201 female 12-year-old Chinese school children, and 61 male and 47 female 12-year-old Caucasian school children were studied (Table 1).

\section{Ethics issue}

The present study was approved by the Institutional Review Board of the University of Hong Kong/Hospital Authority Hong Kong West Cluster (IRB Reference Number: UW 12-405).

\section{Radiographic technique}

One X-ray machine (GE1000, General Electric, Milwaukee, Wits) was used to obtain all lateral cephalograms. The magnification was $8.8 \%$ for the midsaggital structures. The lateral cephalograms were obtained during a natural head posture, in which the subjects looked at the reflection of their eyes in a mirror placed $200 \mathrm{~cm}$ in front of them after first tilting their head forward and backward with decreasing amplitude until a comfortable position of natural balance was found [25].

\section{Cephalometric analysis}

The sample of Chinese children was used to establish cephalometric norms for the upper airway of Chinese boys and girls, respectively. The sample of Caucasian children was used for an ethnic comparison. Published data on the upper airway norms of Chinese adults were used for an age comparison [24]. The demography of all samples is presented in Table 1.

The landmarks and reference lines of the upper airway are shown in the Table 2 and Figure 1. The variables for upper airway measurements included eight linear variables and one angular variable (three variables for the soft palate, four variables for the upper airway depth and two variables for the position of the hyoid bone), which were selected from a previous study on Chinese adults [24]. The analysis of the craniofacial morphology included six linear and eight angular conventional measurements (Table 3 and Figure 2) [11,27]. The analysis was carried out using CASSOS software (Soft Enable Technology Limited, Hong Kong, China). All of the linear measurements were corrected according to the magnification.

\section{Method error}

One examiner (MG) carried out all of the measurements. During the pilot study, the measurements of 10 randomly selected cephalograms were calibrated by another examiner (YQY), and the method error was calculated by Dahlberg's formula [28], $M E=\sqrt{\sum d^{2} / 2 n}$, which is the repeated measurements of 30 randomly selected cephalograms on separated occasions at a 2-week interval. $\Sigma \mathrm{d}$ is the difference between two measurements of a pair, and $\mathrm{n}$ is the number of double measurements. The method errors for the linear and angular measurements

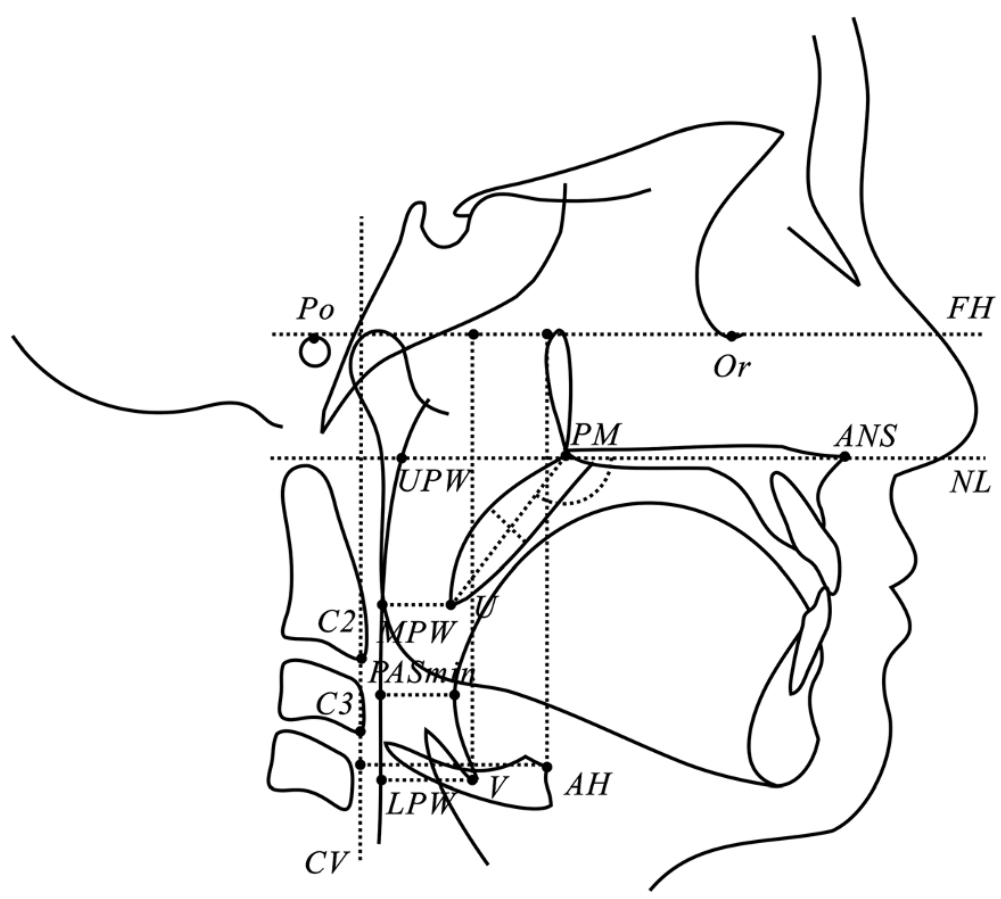

Figure 1 Landmarks and measurements of the upper airway. 
Table 3 Cephalometric landmarks and measurements of the craniofacial structures

\begin{tabular}{|c|c|}
\hline Variables & Definition \\
\hline \multicolumn{2}{|l|}{ Landmarks } \\
\hline$S$ & Center of the sella turcica \\
\hline N & $\begin{array}{l}\text { Nasion, the deepest point in the concavity of } \\
\text { nasofrontal suture }\end{array}$ \\
\hline A & $\begin{array}{l}\text { A point, the deepest point in the concavity of the } \\
\text { anterior maxilla between the anterior nasal spine and } \\
\text { the alveolar crest }\end{array}$ \\
\hline Ui & Upper incisor tip \\
\hline $\mathrm{Li}$ & Lower incisor tip \\
\hline B & $\begin{array}{l}\text { B point, the deepest point in the concavity of the anterior } \\
\text { mandible between the alveolar crest and the pogonion }\end{array}$ \\
\hline Gn & Gnathion, the most anteroinferior point on the bony chin \\
\hline Me & Mention, the most inferior point on the body chin \\
\hline Go' & $\begin{array}{l}\text { Gonion' point, the intersection of the tangents of inferior } \\
\text { and posterior borders of the mandible }\end{array}$ \\
\hline $\operatorname{Ar}$ & $\begin{array}{l}\text { The intersection of the posterior border of the ramus } \\
\text { with inferior surface of the cranial base }\end{array}$ \\
\hline $\mathrm{Cd}$ & $\begin{array}{l}\text { Condylion, the most posterosuperior point of the } \\
\text { condylar head }\end{array}$ \\
\hline $\mathrm{c} 2 \mathrm{sp}$ & $\begin{array}{l}\text { The most superior posterior point of the second cervical } \\
\text { vertebra }\end{array}$ \\
\hline c2ip & $\begin{array}{l}\text { The most inferior posterior point of the second cervical } \\
\text { vertebra }\end{array}$ \\
\hline c4ip & $\begin{array}{l}\text { The most inferior posterior point of the fourth cervical } \\
\text { vertebra }\end{array}$ \\
\hline $\mathrm{MxPI}$ & Maxillary plance, equal to NL (ANS-PM) \\
\hline $\mathrm{MnPI}$ & Mandibular plane, line joining Me and Go \\
\hline OPT & Odontoid process tangent, line joining c2sp and c2ip \\
\hline
\end{tabular}

Measurements

SNA $\left({ }^{\circ}\right) \quad$ The angle between the S-N line and the N-A line

SNB $\left(^{\circ}\right) \quad$ The angle between the S- $N$ line and the N-B line

ANB $\left(^{\circ}\right) \quad$ The angle between the $\mathrm{N}-\mathrm{A}$ line and the $\mathrm{N}-\mathrm{B}$ line

$\mathrm{MnPI} / \mathrm{SN}\left(^{\circ}\right) \quad$ Mandibular plane angle, the angle between the MnPI and the S-N line

$\mathrm{MxPI} / \mathrm{MnPI}\left(^{\circ}\right)$ Maxillomandibular plane angle, the angle between the $\mathrm{MxPI}$ and the MnPI

MxMn-DF Masiilomandibular difference, the length of $\mathrm{Cd}-\mathrm{Gn}$ minus $(\mathrm{mm}) \quad$ the length of Co-A

$\mathrm{TAFH}(\mathrm{mm}) \quad$ The distance from $\mathrm{N}$ to $\mathrm{Me}$

TPFH (mm) The distance from $\mathrm{S}$ to Go

$\mathrm{Y}$ axis/FH $\left(^{\circ}\right) \quad$ The angle between $\mathrm{S}-\mathrm{Gn}$ line and $\mathrm{FH}$ plane

Overjet ( $\mathrm{mm}$ ) The distance between Ui and Li, parallel to the FH plane

Overbite (mm) The distance between Ui and Li, perpendicular to the FH plane

OPT-SN $\left(^{\circ}\right) \quad$ The angle between the OPT and the S-N line

C2sp-c4ip-SN ( ${ }^{\circ}$ ) The angle between the c2sp-c4ip line and the S-N line Body length The distance between Go'-Me $(\mathrm{mm})$ were not statistically significant and did not exceed $1 \mathrm{~mm}$ and $1^{\circ}$, respectively.

\section{Statistical analysis}

The measurements of the upper airway are presented as the mean, median, standard deviation, range and 95\% confidence interval. The Mann-Whitney $U$-test was used to calculate the gender, age and ethnic differences, and the levels of statistical significance were $P<0.05, P<0.01$, and $P<0.001$. The association between the upper airway and the craniofacial structures was analyzed using Spearman rank correlation, and the statistical significance was set at levels of $P<0.05$ and $P<0.01$. Statistical analyses were performed using SPSS software (IBM SPSS Statistics 20, IBM Corp.).

\section{Results}

\section{Gender differences}

In Chinese children, boys had smaller values than girls for almost all of the variables, except for the soft palate thickness (Table 4). The gender differences were statistically significant for soft palate thickness $(P=0.008)$, the depth of the retropalatal $(P=0.011)$ and retroglossal $(P=0.034)$ pharynx, and for the depth of the hypopharynx $(P<0.001)$. No significant gender difference was observed in the Caucasian sample (Table 5).

\section{Age differences}

Chinese adults had statistically significant larger values than Chinese children in both genders for all of the variables except for the inclination of the soft palate in males, and the differences were larger in males (Table 6).

\section{Ethnic differences}

The 12-year-old Chinese children had larger values for all variables (Table 7). In males, the statistically significant differences were found in the shortest distance of the oropharynx $(P=0.019)$, and the position of the hyoid bone in the vertical and horizontal planes $(P=0.014$ and $P=0.001)$; and in females, statistically significant differences were found in the depth of the retroglossal pharynx $(P=0.005)$ and that of the hypopharynx $(P=0.01)$.

\section{Correlations between the upper airway and other craniofacial structures}

The correlations between the upper airway and craniofacial structures were weak, and no correlation coefficient exceeded 0.5. In Chinese children, the variables of the body length of the mandible and the craniocervical inclination were significantly associated with most of the upper airway variables. The vertical and horizontal position of the hyoid bone was significantly associated with anterior and posterior facial height (Table 8). The results for 


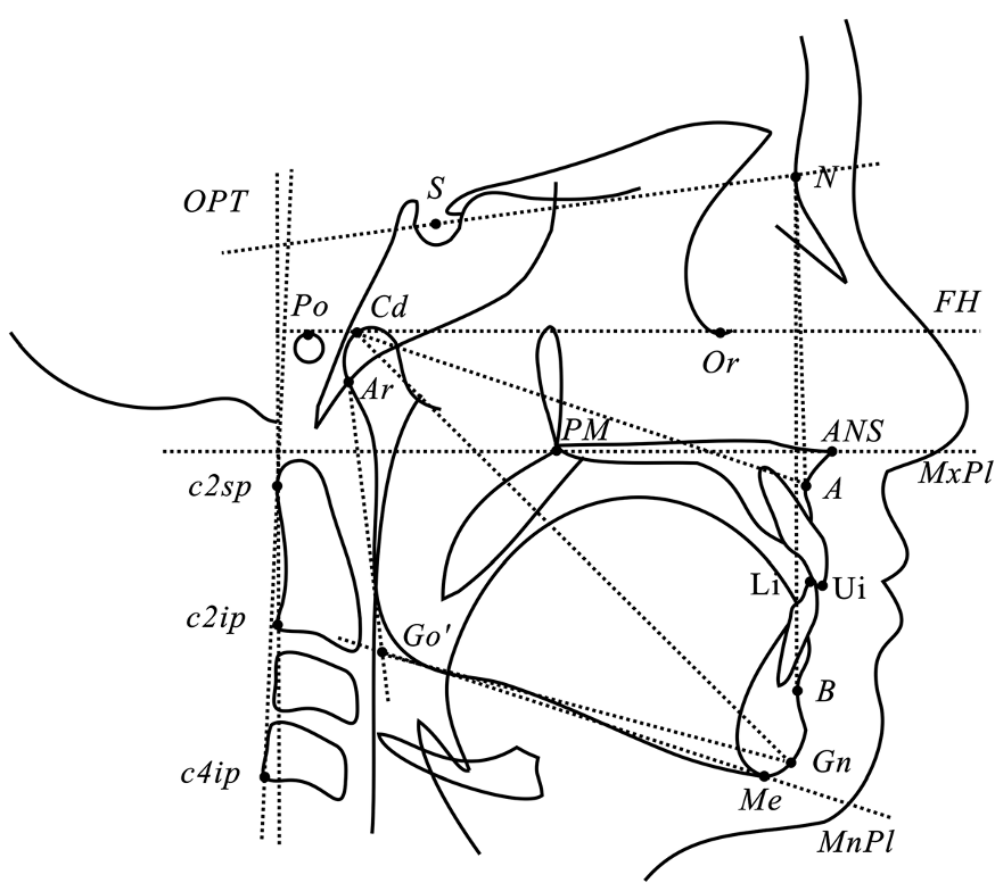

Figure 2 Landmarks and measurements of the craniofacial structures.

the Caucasian children were generally similar to those of the Chinese children (Table 9).

\section{Discussion}

The rationale for the selection of the upper airway variables

In a lateral cephalogram, the observable SDB-related upper airway structures include: the pharynx, the adenoid, the soft palate, the tonsil, the tongue, and the hyoid bone. The pharynx can be divided anatomically into three parts: the nasopharyx, the oropharynx, and the hypopharynx. The oropharynx can be subdivided into the retropalatal and retroglossal pharynxes [29]. In the present study, we therefore selected four variables to represent four parts of the pharynx. The pharyngeal lymphoid tissues, such as the adenoid and tonsils, were not measured because they begin to atrophy from their maximal size during the pre-pubertal years [30]. No tongue measurement was adopted in the present study because the tongue contour was not clear in the cephalograms without barium sulfate paste [31].

\section{The influence of gender on the dimensions of upper airway}

In the present study it was found that Chinese boys had a thicker soft palate and less depth in the retropalatal, retroglossal and hypopharyngeal regions of the upper airway. It has suggested that these characteristics were related to pediatric SDB $[8,10]$, which may explain why Hong Kong boys had a higher prevalence of OSAS than Hong Kong girls (5.8\% versus 3.8\%) [32]. In the present there was no difference in the upper airway dimensions of Caucasian boys and girls. Interestingly, no gender difference has been reported in the prevalence of OSAS in Caucasian children by most of studies [5]. Therefore, the upper airway dimensions may be a crucial risk factor of pediatric SDB. However, this seems not to be valid in adults, because men generally have a larger size of pharyngeal lumen than women, but have a higher prevalence of SDB; Subsequently, other factors such as differences in hormones, chemosensitivity and tissue properties may be more important in adult SDB than airway dimensions [29].

\section{The influence of age on the dimensions of the upper airway}

In the present study, the 12-year-old Chinese children, especially the boys, were found to have much growth potential in all of the upper airway structures from childhood to adulthood. The soft palate tended to increase in length, thickness, and inclination, the depth of the pharynx increased at all of the levels, and the hyoid bone moved anteriorly and inferiorly. Chinese boys had more prominent upper airway changes than Chinese girls. In 12-year-olds, Chinese boys had less depth of the pharynx, but they had a larger pharynx in adulthood, showing that Chinese boys have a later spurt in growth compared with Chinese girls. This phenomenon is corresponding to the sexual dimorphism in craniofacial growth [33]. The similar finding was also reported by other lateral cephalometric analysis or 3-dimentional CT research [34,35]. In addition, Taylor et al. [36] reported that the growth of the oropharynx 


\section{Table 4 Cephalometric norms of upper airway in Chinese subjects and gender differences}

\begin{tabular}{|c|c|c|c|c|c|c|c|c|c|c|c|c|c|c|c|c|c|c|}
\hline \multirow[t]{3}{*}{ Variables } & & \multicolumn{7}{|c|}{ Boys } & \multicolumn{7}{|c|}{ Girls } & \multirow{3}{*}{$\begin{array}{l}\text { Gender } \\
\text { difference }\end{array}$} & \multirow{3}{*}{\multicolumn{2}{|c|}{$P$ value }} \\
\hline & & \multirow[b]{2}{*}{ Mean } & \multirow[b]{2}{*}{ SD } & \multirow[b]{2}{*}{ Median } & \multicolumn{2}{|c|}{ Range } & \multicolumn{2}{|c|}{$95 \% \mathrm{Cl}$} & \multirow[b]{2}{*}{ Mean } & \multirow[b]{2}{*}{ SD } & \multirow[b]{2}{*}{ Median } & \multicolumn{2}{|c|}{ Range } & \multicolumn{2}{|c|}{$95 \% \mathrm{Cl}$} & & & \\
\hline & & & & & Min & $\operatorname{Max}$ & Lower & Upper & & & & Min & $\operatorname{Max}$ & Lower & Upper & & & \\
\hline \multicolumn{19}{|l|}{ Soft palate } \\
\hline PM-U & Length of the soft palate & 29.6 & 3.4 & 29.9 & 21.0 & 38.0 & 29.2 & 30.1 & 29.3 & 3.4 & 29.1 & 22.0 & 45.3 & 28.9 & 29.8 & 0.3 & 0.271 & \\
\hline SPT & Soft palate thickness & 8.3 & 1.2 & 8.3 & 4.1 & 11.9 & 8.2 & 8.5 & 8.0 & 1.4 & 7.9 & 2.8 & 12.7 & 7.8 & 8.2 & 0.3 & 0.008 & ** \\
\hline NL/PM-U & $\begin{array}{l}\text { Inclination of the long axis of the soft palate } \\
\text { relative to the nasal line }\end{array}$ & 125.9 & 6.1 & 125.5 & 109.1 & 144.2 & 125.1 & 126.7 & 126.9 & 5.4 & 127.1 & 112.9 & 144.8 & 126.2 & 127.7 & -1.0 & 0.058 & \\
\hline \multicolumn{19}{|c|}{ Depth of upper airway } \\
\hline PM-UPW & Depth of the nasopharyngeal airway space & 21.0 & 3.5 & 21.2 & 4.7 & 28.4 & 20.5 & 21.4 & 20.9 & 3.5 & 20.9 & 11.1 & 28.4 & 20.4 & 21.4 & 0.1 & 0.553 & \\
\hline U-MPW & Depth of the retropalatal pharyngeal airway space & 8.7 & 2.2 & 8.6 & 3.4 & 14.8 & 8.4 & 9.0 & 9.2 & 2.4 & 9.2 & 3.5 & 16.0 & 8.9 & 9.6 & -0.6 & 0.011 & * \\
\hline V-LPW & Depth of the hypopharyngeal airway space & 13.4 & 3.0 & 13.9 & 5.0 & 19.9 & 13.0 & 13.8 & 14.5 & 3.1 & 14.7 & 5.2 & 23.2 & 14.1 & 15.0 & -1.1 & $<0.001$ & *** \\
\hline PASmin & Depth of the retroglossal pharyngeal airway space & 8.4 & 2.5 & 8.4 & 2.3 & 14.3 & 8.1 & 8.8 & 9.0 & 2.7 & 8.8 & 2.8 & 16.5 & 8.7 & 9.4 & -0.6 & 0.034 & * \\
\hline \multicolumn{19}{|c|}{ Position of the hyoid bone } \\
\hline $\mathrm{AH}-\mathrm{FH}$ & Positon of the hyoid bone in the vertical plance & 75.2 & 5.9 & 75.2 & 60.8 & 95.3 & 74.3 & 75.9 & 74.1 & 6.0 & 73.9 & 58.9 & 99.1 & 73.2 & 74.9 & 1.1 & 0.04 & \\
\hline $\mathrm{AH}-\mathrm{CV}$ & Positon of the hyoid bone in the horizontal plance & 30.1 & 3.4 & 30.1 & 21.1 & 37.9 & 29.6 & 30.5 & 30.2 & 3.0 & 30.4 & 22.9 & 41.1 & 29.8 & 30.7 & -0.2 & 0.775 & \\
\hline
\end{tabular}

${ }^{*} p<0.05 ;{ }^{* *} p<0.01 ;{ }^{* * *} p<0.001$. 
Table 5 Cephalometric values of upper airway in Caucasian subjects and gender differences

\begin{tabular}{|c|c|c|c|c|c|c|c|c|c|c|c|c|c|c|c|c|c|}
\hline \multirow[t]{3}{*}{ Variables } & & \multicolumn{7}{|c|}{ Boys } & \multicolumn{7}{|c|}{ Girls } & \multirow{3}{*}{$\begin{array}{l}\text { Gender } \\
\text { difference }\end{array}$} & \multirow[t]{3}{*}{$P$ value } \\
\hline & & \multirow[b]{2}{*}{ Mean } & \multirow[b]{2}{*}{ SD } & \multirow[b]{2}{*}{ Median } & \multicolumn{2}{|c|}{ Range } & \multicolumn{2}{|c|}{$95 \% \mathrm{Cl}$} & \multirow[b]{2}{*}{ Mean } & \multirow[b]{2}{*}{ SD } & \multirow[b]{2}{*}{ Median } & \multicolumn{2}{|c|}{ Range } & \multicolumn{2}{|c|}{$95 \% \mathrm{Cl}$} & & \\
\hline & & & & & Min & $\operatorname{Max}$ & Lower & Upper & & & & Min & $\operatorname{Max}$ & Lower & Upper & & \\
\hline \multicolumn{18}{|c|}{ Soft palate } \\
\hline PM-U & Length of the soft palate & 29.9 & 3.9 & 29.7 & 20.2 & 42.6 & 28.8 & 30.9 & 29.4 & 3.3 & 29.2 & 23.5 & 37.9 & 28.4 & 30.4 & 0.5 & 0.377 \\
\hline SPT & Soft palate thickness & 8.3 & 1.3 & 8.4 & 5.2 & 11.8 & 8.0 & 8.7 & 7.9 & 1.1 & 7.9 & 5.8 & 10.8 & 7.6 & 8.2 & 0.4 & 0.055 \\
\hline $\mathrm{NL} / \mathrm{PM}-\mathrm{U}$ & $\begin{array}{l}\text { Inclination of the long axis of the soft palate } \\
\text { relative to the nasal line }\end{array}$ & 124.6 & 6.3 & 125.0 & 111.0 & 140.0 & 123.0 & 126.2 & 126.8 & 6.8 & 125.0 & 113.0 & 147.0 & 124.8 & 128.8 & -2.2 & 0.296 \\
\hline \multicolumn{18}{|c|}{ Depth of upper airway } \\
\hline PM-UPW & Depth of the nasopharyngeal airway space & 21.0 & 3.6 & 21.6 & 9.9 & 27.3 & 20.1 & 21.9 & 21.1 & 4.1 & 21.0 & 8.2 & 31.7 & 19.9 & 22.3 & -0.1 & 1.000 \\
\hline U-MPW & Depth of the retropalatal pharyngeal airway space & 9.1 & 2.4 & 9.1 & 3.1 & 13.8 & 8.5 & 9.7 & 9.2 & 2.3 & 8.8 & 4.3 & 14.2 & 8.5 & 9.8 & -0.1 & 0.889 \\
\hline V-LPW & Depth of the hypopharyngeal airway space & 13.1 & 2.5 & 13.5 & 8.0 & 19.7 & 12.5 & 13.8 & 13.1 & 3.4 & 13.6 & 7.4 & 21.0 & 12.2 & 14.1 & 0.0 & 0.973 \\
\hline PASmin & Depth of the retroglossal pharyngeal airway space & 7.5 & 2.8 & 7.4 & 2.8 & 13.8 & 6.8 & 8.2 & 7.9 & 2.8 & 7.3 & 4.1 & 14.7 & 7.1 & 8.7 & -0.4 & 0.562 \\
\hline \multicolumn{18}{|c|}{ Position of the hyoid bone } \\
\hline $\mathrm{AH}-\mathrm{FH}$ & Positon of the hyoid bone in the vertical plance & 73.1 & 5.4 & 72.8 & 62.6 & 84.2 & 71.7 & 74.4 & 72.8 & 5.2 & 72.2 & 60.1 & 85.9 & 71.3 & 74.3 & 0.3 & 0.633 \\
\hline $\mathrm{AH}-\mathrm{CV}$ & Positon of the hyoid bone in the horizontal plance & 28.6 & 2.9 & 28.8 & 22.0 & 35.5 & 27.8 & 29.3 & 29.4 & 3.0 & 29.4 & 24.2 & 35.6 & 28.5 & 30.3 & -0.8 & 0.208 \\
\hline
\end{tabular}


Table 6 Cephalometric values of the upper airway for interethnic differences (Chinese versus Caucasian)

\begin{tabular}{|c|c|c|c|c|c|c|c|}
\hline \multirow[t]{2}{*}{ Variables } & & \multicolumn{2}{|c|}{ Boys } & & \multicolumn{2}{|c|}{ Girls } & \\
\hline & & Mean & $P$ value & & Mean & $P$ value & \\
\hline \multicolumn{7}{|l|}{ Soft palate } & \\
\hline $\mathrm{PM}-\mathrm{U}$ & Length of the soft palate & -0.2 & 0.681 & & -0.1 & 0.954 & \\
\hline SPT & Soft palate thickness & 0.0 & 0.827 & & 0.0 & 0.714 & \\
\hline NL/PM-U & Inclination of the long axis of the soft palate relative to the nasal line & 1.3 & 0.252 & & 0.2 & 0.456 & \\
\hline \multicolumn{7}{|c|}{ Depth of upper airway } & \\
\hline PM-UPW & Depth of the nasopharyngeal airway space & 0.0 & 0.914 & & -0.2 & 0.738 & \\
\hline U-MPW & Depth of the retropalatal pharyngeal airway space & -0.4 & 0.146 & & 0.1 & 0.724 & \\
\hline V-LPW & Depth of the hypopharyngeal airway space & 0.3 & 0.314 & & 1.4 & 0.01 & $* *$ \\
\hline PASmin & Depth of the retroglossal pharyngeal airway space & 0.9 & 0.019 & * & 1.1 & 0.005 & ** \\
\hline \multicolumn{7}{|c|}{ Position of the hyoid bone } & \\
\hline $\mathrm{AH}-\mathrm{FH}$ & Positon of the hyoid bone in the vertical plance & 2.1 & 0.014 & * & 1.3 & 0.114 & \\
\hline $\mathrm{AH}-\mathrm{CV}$ & Positon of the hyoid bone in the horizontal plance & 1.5 & 0.001 & $* *$ & 0.9 & 0.074 & \\
\hline
\end{tabular}

has two periods of accelerated change (6-9 years and 12-15 years) and two periods of quiescence (9-12 years and 15-18 years) for the growth of oropharynx, but Mislik et al. [37] found there was no radical change in the retropalatal and retroglossal oropharynx from 6 to 17 years of age, and considered that the upper airway dimensions were formed and matured during the early periods of growth. Because the chronological regularity of growth of Chinese children is still unclear, we consider that the norms obtained from 12-year-old Chinese children are only relevant to the age around 12-year-old. Wu et al. [38] used the same sample of 12-year-old Chinese children data to get the Chinese norms of McNamara's analysis and suggested that the norms were suitable for around 10-14 years age.
Whether the age range of 10-14 years old is also suitable for upper airway needs further investigation.

\section{The influence of ethnicity on the dimensions of the upper airway}

The prevalence of SDB has been reported to show ethnic/ racial differences. African-Americans were considered to have a higher incidence of OSAS than Caucasians [39], and Indians were reported to have a greater risk of SDB than Chinese [40]. No published research has compared the prevalence of pediatric SDB between Chinese and Caucasian children. The present study found the ethnic differences in the upper airways in 12-year-old Caucasian and Chinese children. Both genders of Chinese children

Table 7 Cephalometric values of the upper airway for age differences (adults versus children)

\begin{tabular}{|c|c|c|c|c|c|c|c|}
\hline \multirow[t]{2}{*}{ Variables } & & \multicolumn{2}{|c|}{ Males } & & \multicolumn{2}{|c|}{ Females } & \\
\hline & & Mean & $P$ value & & Mean & $P$ value & \\
\hline \multicolumn{8}{|l|}{ Soft palate } \\
\hline$P M-U$ & Length of the soft palate & 4.7 & $<0.001$ & $* * *$ & 1.3 & 0.009 & $* *$ \\
\hline SPT & Soft palate thickness & 1.8 & $<0.001$ & $* * *$ & 0.9 & $<0.001$ & $* * *$ \\
\hline $\mathrm{NL} / \mathrm{PM}-\mathrm{U}$ & Inclination of the long axis of the soft palate relative to the nasal line & 1.4 & 0.119 & & 1.4 & 0.039 & * \\
\hline \multicolumn{8}{|c|}{ Depth of upper airway } \\
\hline PM-UPW & Depth of the nasopharyngeal airway space & 4.9 & $<0.001$ & $* * *$ & 3.2 & $<0.001$ & $* * *$ \\
\hline U-MPW & Depth of the retropalatal pharyngeal airway space & 1.2 & 0.017 & * & 0.7 & 0.027 & * \\
\hline V-LPW & Depth of the hypopharyngeal airway space & 5.3 & $<0.001$ & $* * *$ & 2.0 & $<0.001$ & $* * *$ \\
\hline PASmin & Depth of the retroglossal pharyngeal airway space & 1.7 & 0.002 & $* *$ & 1.0 & 0.008 & ** \\
\hline \multicolumn{8}{|c|}{ Position of the hyoid bone } \\
\hline $\mathrm{AH}-\mathrm{FH}$ & Positon of the hyoid bone in the vertical plance & 17.2 & $<0.001$ & $* * *$ & 4.4 & $<0.001$ & $* * *$ \\
\hline $\mathrm{AH}-\mathrm{CV}$ & Positon of the hyoid bone in the horizontal plance & 6.3 & $<0.001$ & $* * *$ & 1.0 & 0.009 & ** \\
\hline
\end{tabular}

${ }^{*} p<0.05 ;{ }^{* *} p<0.01 ;{ }^{* * *} p<0.001$. 
Table 8 Results of Spearman's correlation analysis for Chinese samples

\begin{tabular}{|c|c|c|c|c|c|c|c|c|c|c|c|c|c|c|c|c|c|c|c|}
\hline & & \multicolumn{5}{|c|}{ Soft palate } & \multicolumn{8}{|c|}{ Depth of the upper airway } & \multicolumn{5}{|c|}{$\begin{array}{l}\text { Position of the hyoid } \\
\text { bone }\end{array}$} \\
\hline & & PM-U & & SPT & & $\overline{N L / P M-U}$ & & PM-UPW & & U-MPW & & V-LPW & & PASmin & & AH-FH & & $\mathrm{AH}-\mathrm{CV}$ & \\
\hline \multirow[t]{2}{*}{ SNA $\left(^{\circ}\right)$} & Coefficient & -0.044 & & 0.061 & & -0.167 & $* *$ & 0.047 & & 0.085 & & 0.042 & & 0.042 & & 0.011 & & 0.064 & \\
\hline & $P$ value & 0.367 & & 0.211 & & 0.001 & & 0.337 & & 0.082 & & 0.389 & & 0.392 & & 0.826 & & 0.185 & \\
\hline \multirow[t]{2}{*}{ SNB $\left(^{\circ}\right)$} & Coefficient & -0.104 & * & 0.066 & & -0.210 & $* *$ & 0.038 & & 0.156 & $* *$ & 0.101 & $*$ & 0.123 & * & -0.019 & & 0.138 & \\
\hline & $P$ value & 0.032 & & 0.173 & & 0.000 & & 0.439 & & 0.001 & & 0.037 & & 0.011 & & 0.703 & & 0.004 & \\
\hline \multirow[t]{2}{*}{ ANB $\left(^{\circ}\right)$} & Coefficient & 0.124 & * & -0.015 & & 0.095 & & 0.026 & & -0.133 & $* *$ & -0.083 & & -0.135 & $* *$ & 0.045 & & -0.099 & \\
\hline & $P$ value & 0.010 & & 0.753 & & 0.049 & & 0.595 & & 0.006 & & 0.089 & & 0.005 & & 0.358 & & 0.041 & \\
\hline \multirow[t]{2}{*}{$\mathrm{MnPI} / \mathrm{SN}\left({ }^{\circ}\right)$} & Coefficient & 0.000 & & -0.046 & & 0.044 & & -0.111 & $*$ & -0.115 & $*$ & -0.099 & $*$ & -0.068 & & 0.000 & & -0.121 & \\
\hline & $P$ value & 0.997 & & 0.349 & & 0.368 & & 0.022 & & 0.018 & & 0.042 & & 0.164 & & 0.997 & & 0.012 & \\
\hline \multirow[t]{2}{*}{$\mathrm{MxPI} / \mathrm{MnPI}\left({ }^{\circ}\right)$} & Coefficient & -0.088 & & -0.102 & $*$ & 0.179 & $* *$ & -0.023 & & -0.070 & & -0.039 & & -0.025 & & 0.061 & & -0.099 & \\
\hline & $P$ value & 0.071 & & 0.035 & & 0.000 & & 0.632 & & 0.153 & & 0.428 & & 0.603 & & 0.212 & & 0.042 & \\
\hline \multirow[t]{2}{*}{$\mathrm{MxMn-DF}(\mathrm{mm})$} & Coefficient & 0.019 & & 0.174 & $* *$ & -0.191 & $* *$ & -0.056 & & 0.110 & $*$ & 0.154 & $* *$ & 0.089 & & 0.263 & $* *$ & 0.251 & $*$ \\
\hline & $P$ value & 0.701 & & 0.000 & & 0.000 & & 0.252 & & 0.023 & & 0.001 & & 0.067 & & 0.000 & & 0.000 & \\
\hline \multirow[t]{2}{*}{ TAFH (mm) } & Coefficient & 0.237 & $* *$ & 0.208 & $* *$ & -0.018 & & 0.112 & $*$ & 0.062 & & 0.126 & $*$ & 0.042 & & 0.489 & $* *$ & 0.304 & $*$ \\
\hline & $P$ value & 0.000 & & 0.000 & & 0.718 & & 0.021 & & 0.203 & & 0.009 & & 0.383 & & 0.000 & & 0.000 & \\
\hline \multirow[t]{2}{*}{ TPFH (mm) } & Coefficient & 0.201 & $* *$ & 0.210 & $* *$ & -0.080 & & 0.138 & $* *$ & 0.138 & $* *$ & 0.198 & $* *$ & 0.068 & & 0.417 & $* *$ & 0.389 & $*$ \\
\hline & $P$ value & 0.000 & & 0.000 & & 0.100 & & 0.004 & & 0.004 & & 0.000 & & 0.161 & & 0.000 & & 0.000 & \\
\hline \multirow[t]{2}{*}{$\mathrm{Y}$ axis/FH $\left({ }^{\circ}\right)$} & Coefficient & 0.122 & $*$ & -0.083 & & 0.065 & & -0.013 & & -0.159 & $* *$ & -0.057 & & -0.141 & $* *$ & 0.139 & $* *$ & -0.058 & \\
\hline & $P$ value & 0.012 & & 0.086 & & 0.184 & & 0.789 & & 0.001 & & 0.245 & & 0.004 & & 0.004 & & 0.230 & \\
\hline \multirow[t]{2}{*}{ Overjet (mm) } & Coefficient & 0.084 & & -0.034 & & 0.090 & & -0.001 & & -0.180 & $* *$ & -0.081 & & -0.232 & $* *$ & 0.181 & $* *$ & -0.089 & \\
\hline & $P$ value & 0.085 & & 0.487 & & 0.062 & & 0.990 & & 0.000 & & 0.095 & & 0.000 & & 0.000 & & 0.068 & \\
\hline \multirow[t]{2}{*}{ Overbite (mm) } & Coefficient & 0.135 & $* *$ & -0.048 & & 0.023 & & 0.019 & & -0.134 & $* *$ & -0.044 & & -0.150 & $* *$ & 0.080 & & -0.126 & \\
\hline & value & 0.005 & & 0.324 & & 0.637 & & 0.690 & & 0.006 & & 0.369 & & 0.002 & & 0.100 & & 0.009 & \\
\hline \multirow[t]{2}{*}{ OPT-SN $\left({ }^{\circ}\right)$} & Coefficient & 0.179 & $* *$ & -0.053 & & 0.336 & $* *$ & -0.089 & & -0.017 & & 0.299 & $* *$ & 0.212 & $* *$ & 0.142 & $* *$ & 0.335 & $*$ \\
\hline & $P$ value & 0.000 & & 0.278 & & 0.000 & & 0.066 & & 0.726 & & 0.000 & & 0.000 & & 0.003 & & 0.000 & \\
\hline \multirow[t]{2}{*}{ c2sp-c4ip-SN $\left(^{\circ}\right)$} & Coefficient & 0.195 & $* *$ & -0.055 & & 0.316 & $* *$ & -0.103 & & -0.043 & & 0.289 & $* *$ & 0.169 & $* *$ & 0.171 & $* *$ & 0.278 & $*$ \\
\hline & $P$ value & 0.000 & & 0.257 & & 0.000 & & 0.033 & & 0.375 & & 0.000 & & 0.000 & & 0.000 & & 0.000 & \\
\hline \multirow[t]{2}{*}{ Body length (mm) } & Coefficient & 0.051 & & 0.158 & $* *$ & -0.024 & & 0.166 & $* *$ & 0.204 & $* *$ & 0.206 & $* *$ & 0.224 & $* *$ & 0.290 & $* *$ & 0.302 & \\
\hline & $P$ value & 0.296 & & 0.001 & & 0.627 & & 0.001 & & 0.000 & & 0.000 & & 0.000 & & 0.000 & & 0.000 & \\
\hline
\end{tabular}

*Correlation is significant at the 0.05 level.

${ }^{*}$ Correlation is significant at the 0.01 level.

had a larger depth of retroglossal oropharynx than their Caucasian counterparts, and Chinese boys had a more anterior and inferior position of the hyoid bone. It is impossible to predict the difference in the risk of SDB between Chinese or Caucasian children based on these findings, because the larger size of pharynx is considered an advantage for airway patency but the anterior and inferior position of the hyoid bone is a disadvantage [17].

\section{The associations between the upper airway and other craniofacial structures}

The present study found that the associations between the craniofacial structures and the upper airway were generally weak, but the mandibular length and craniocervical inclination were found to have more prominent associations with most of the upper airway variables than the other craniofacial structures in both Chinese and Caucasian ethnicities. Ozdemir et al. [41] also reported the a positive association between mandibular body length (GnGo) and minimal posterior airway space (MPAS). The finding seems to indicate that skeletal Class II malocclusion is a risk factor for pediatric SDB. The influence of craniocervical inclination on the dimensions of upper airway has been reported in a number of studies [42-44]. An increase in the craniocervical extension tends to increase the depth of the pharynx, and it was reported to be one of the craniofacial characteristics of children with SDB [19]. 
Table 9 Results of Spearman's correlation analysis for Caucasian samples

\begin{tabular}{|c|c|c|c|c|c|c|c|c|c|c|c|c|c|c|c|c|c|c|}
\hline \multirow[t]{2}{*}{ Variables } & & \multicolumn{5}{|c|}{ Soft palate } & & \multicolumn{7}{|c|}{ Depth of the upper airway } & \multicolumn{4}{|c|}{$\begin{array}{l}\text { Position of the hyoid } \\
\text { bone }\end{array}$} \\
\hline & & PM-U & & SPT & & NL/PM-U & & PM-UPW & & U-MPW & & V-LPW & & PASmin & $\overline{\mathrm{AH}-\mathrm{FH}}$ & & AH-CV & \\
\hline \multirow[t]{2}{*}{ SNA $\left(^{\circ}\right)$} & Coefficient & -0.010 & & 0.111 & & 0.001 & & 0.178 & & -0.088 & & 0.040 & & -0.075 & -0.068 & & 0.033 & \\
\hline & $P$ value & 0.919 & & 0.252 & & 0.991 & & 0.066 & & 0.365 & & 0.684 & & 0.439 & 0.484 & & 0.738 & \\
\hline \multirow[t]{2}{*}{ SNB $\left(^{\circ}\right)$} & Coefficient & -0.064 & & 0.223 & * & -0.106 & & 0.119 & & -0.098 & & -0.009 & & -0.099 & -0.032 & & 0.081 & \\
\hline & $P$ value & 0.508 & & 0.021 & & 0.276 & & 0.221 & & 0.311 & & 0.925 & & 0.308 & 0.742 & & 0.404 & \\
\hline \multirow[t]{2}{*}{ ANB $\left(^{\circ}\right)$} & Coefficient & 0.135 & & -0.134 & & 0.252 & $* *$ & 0.200 & $*$ & -0.069 & & 0.064 & & -0.005 & -0.093 & & -0.029 & \\
\hline & $P$ value & 0.162 & & 0.166 & & 0.008 & & 0.038 & & 0.476 & & 0.510 & & 0.958 & 0.337 & & 0.769 & \\
\hline \multirow[t]{2}{*}{$\mathrm{MnPI} / \mathrm{SN}\left({ }^{\circ}\right)$} & Coefficient & 0.026 & & -0.057 & & 0.103 & & -0.137 & & 0.145 & & -0.027 & & 0.065 & 0.117 & & -0.043 & \\
\hline & $P$ value & 0.788 & & 0.557 & & 0.291 & & 0.157 & & 0.133 & & 0.781 & & 0.506 & 0.229 & & 0.657 & \\
\hline \multirow[t]{2}{*}{$\mathrm{MxPI} / \mathrm{MnPI}\left({ }^{\circ}\right)$} & Coefficient & -0.022 & & -0.105 & & 0.236 & $*$ & 0.019 & & 0.104 & & -0.055 & & -0.064 & 0.204 & $*$ & -0.100 & \\
\hline & $P$ value & 0.824 & & 0.281 & & 0.014 & & 0.842 & & 0.285 & & 0.573 & & 0.510 & 0.034 & & 0.302 & \\
\hline \multirow[t]{2}{*}{$\mathrm{MxMn-DF}(\mathrm{mm})$} & Coefficient & 0.050 & & 0.274 & $* *$ & -0.079 & & -0.065 & & 0.094 & & -0.052 & & 0.023 & 0.423 & $* *$ & 0.153 & \\
\hline & $P$ value & 0.609 & & 0.004 & & 0.417 & & 0.502 & & 0.332 & & 0.592 & & 0.813 & 0.000 & & 0.113 & \\
\hline \multirow[t]{2}{*}{ TAFH (mm) } & Coefficient & 0.240 & $*$ & 0.180 & & 0.120 & & 0.041 & & 0.086 & & 0.217 & $*$ & 0.188 & 0.444 & $* *$ & 0.302 & \\
\hline & $P$ value & 0.012 & & 0.063 & & 0.215 & & 0.673 & & 0.373 & & 0.024 & & 0.051 & 0.000 & & 0.001 & \\
\hline \multirow[t]{2}{*}{ TPFH (mm) } & Coefficient & 0.257 & $* *$ & 0.269 & $* *$ & -0.082 & & 0.062 & & -0.081 & & 0.271 & $* *$ & 0.152 & 0.348 & $* *$ & 0.291 & \\
\hline & $P$ value & 0.007 & & 0.005 & & 0.397 & & 0.521 & & 0.402 & & 0.005 & & 0.117 & 0.000 & & 0.002 & \\
\hline \multirow[t]{2}{*}{$\mathrm{Y}$ axis/FH $\left({ }^{\circ}\right)$} & Coefficient & 0.188 & & -0.139 & & 0.003 & & -0.141 & & -0.115 & & 0.083 & & -0.030 & 0.178 & & -0.079 & \\
\hline & $P$ value & 0.051 & & 0.153 & & 0.978 & & 0.147 & & 0.236 & & 0.395 & & 0.757 & 0.065 & & 0.415 & \\
\hline \multirow[t]{2}{*}{ Overjet (mm) } & Coefficient & -0.053 & & -0.199 & $*$ & 0.140 & & 0.037 & & -0.057 & & -0.050 & & -0.165 & 0.096 & & 0.033 & \\
\hline & $P$ value & 0.583 & & 0.039 & & 0.150 & & 0.701 & & 0.560 & & 0.608 & & 0.087 & 0.322 & & 0.736 & \\
\hline \multirow[t]{2}{*}{ Overbite (mm) } & Coefficient & 0.063 & & -0.034 & & 0.117 & & 0.120 & & -0.154 & & -0.076 & & -0.206 & -0.064 & & -0.150 & \\
\hline & $P$ value & 0.519 & & 0.729 & & 0.229 & & 0.215 & & 0.112 & & 0.436 & & 0.033 & 0.510 & & 0.120 & \\
\hline \multirow[t]{2}{*}{ OPT-SN $\left({ }^{\circ}\right)$} & Coefficient & 0.199 & $*$ & -0.239 & $*$ & 0.417 & $* *$ & 0.038 & & 0.302 & $* *$ & 0.353 & $* *$ & 0.404 & 0.201 & $*$ & 0.326 & * \\
\hline & $P$ value & 0.039 & & 0.013 & & 0.000 & & 0.693 & & 0.001 & & 0.000 & & 0.000 & 0.037 & & 0.001 & \\
\hline \multirow[t]{2}{*}{ c2sp-c4ip-SN $\left(^{\circ}\right)$} & Coefficient & 0.213 & $*$ & -0.209 & $*$ & 0.376 & $* *$ & 0.013 & & 0.253 & $* *$ & 0.336 & $* *$ & 0.360 & 0.202 & $*$ & 0.278 & $*$ \\
\hline & $P$ value & 0.027 & & 0.030 & & 0.000 & & 0.892 & & 0.008 & & 0.000 & & 0.000 & 0.036 & & 0.004 & \\
\hline \multirow[t]{2}{*}{ Body length (mm) } & Coefficient & -0.079 & & 0.073 & & 0.206 & $*$ & 0.318 & $* *$ & 0.280 & $* *$ & 0.136 & & 0.212 & 0.210 & $*$ & 0.235 & \\
\hline & $P$ value & 0.414 & & 0.451 & & 0.033 & & 0.001 & & 0.003 & & 0.159 & & 0.028 & 0.029 & & 0.014 & \\
\hline
\end{tabular}

*Correlation is significant at the 0.05 level.

**Correlation is significant at the 0.01 level.

\section{The limitations of the present study}

Firstly, because the samples were not from a study that focused on the upper airway, no history-related investigation of the upper airway was made, such as diagnosis of SDB, snoring, enlarged tonsils, or history of adenotonsillectomy, etc. Secondly, the original lateral radiograph technique was not adopted especially for the upper airway, i.e., the radiographs were taken at the end of expiration, by holding the latter position and refraining from swallowing while the film was exposed [31]. These two factors had some influence on the dimensions of the upper airway, but as the present study was based on a large sample size, and we excluded the cephalograms in which a swallowing action was detected, the reference values derived in this study can represent the norms of children in this age group. Thirdly, transversal airway dimension could not be analyzed due to the limitation of two-dimensional lateral cephalometry.

\section{Conclusions}

1. Cephalometric norms for the upper airway of Chinese children have been established providing gender-specific standards. Chinese boys tend to have more risk factors of upper airway for SDB than Chinese girls.

2. Ethnic differences were found in the upper airway dimensions between Chinese and Caucasian children. Chinese children had a greater depth of the retroglossal oropharynx, and Chinese boys had a 
more anterior and inferior position of the hyoid bone than Caucasian boys.

3. Generally, the associations between the upper airway and craniofacial structures were weak, but the mandibular body length and the craniocervical inclination seemed to have a more prominent correlation with the upper airway than other craniofacial structures.

\section{Competing interests}

The authors declare that they have no financial and non-financial competing interest. This study was funded by the research funding of the University of Hong Kong.

\section{Authors' contributions}

MG carried out the cephalometric analysis, drafted and finalized the manuscript. CPJM, RWKW, UH and YQY participated the design of the study, interpreted the data and revised the manuscript. All authors read and approved the final manuscript.

\section{Authors' information}

MG, Clinical Assistant Professor, Department of Paediatric Dentistry and Orthodontics, Faculty of Dentistry, The University of Hong Kong, Hong Kong SAR, China

CPJM, Clinical Professor, Department of Dental Public Health, Faculty of Dentistry, The University of Hong Kong, Hong Kong SAR, China RWKW, Consultant, Department of Dentistry and Maxillofacial Surgery Cleft Center (Craniofacial Orthodontics), United Christian Hospital, Hong Kong SAR, China

UH, Emeritus Professor, Faculty of Dentistry, The University of Hong Kong, Hong Kong SAR, China

YQY, Clinical Assistant Professor, Department of Paediatric Dentistry and Orthodontics, Faculty of Dentistry, The University of Hong Kong, Hong Kong SAR, China

\section{Acknowledgements}

We express our thanks to Dr. MS Cooke who obtained the lateral cephalograms from the oral health survey of 12-year-old children held in 1984-85 and Dr. John Wu who provided suggestion on data analysis.

\section{Author details}

${ }^{1}$ Orthodontics, Faculty of Dentistry, the University of Hong Kong, 34 Hospital Road, Hong Kong, SAR, China. ${ }^{2}$ Public Health, Faculty of Dentistry, the University of Hong Kong, 34 Hospital Road, Hong Kong, SAR, China. ${ }^{3}$ Department of Dentistry and Maxillofacial Surgery Cleft Centre, United Christian Hospital, Hong Kong, SAR, China.

\section{Received: 19 August 2014 Accepted: 8 September 2014}

\section{Published: 13 September 2014}

\section{References}

1. Katyal V, Pamula Y, Martin AJ, Daynes CN, Kennedy JD, Sampson WJ: Craniofacial and upper airway morphology in pediatric sleep-disordered breathing: Systematic review and meta-analysis. Am J Orthod Dentofacial Orthop 2013, 143(1):20-30 e23.

2. Flores-Mir C, Korayem M, Heo G, Witmans M, Major MP, Major PW: Craniofacial morphological characteristics in children with obstructive sleep apnea syndrome: a systematic review and meta-analysis. J Am Dent Assoc 2013, 144(3):269-277.

3. Katz ES, D'Ambrosio CM: Pathophysiology of pediatric obstructive sleep apnea. Proc Am Thorac Soc 2008, 5(2):253-262.

4. Carroll JL: Obstructive sleep-disordered breathing in children: new controversies, new directions. Clin Chest Med 2003, 24(2):261-282.

5. Marcus CL, Brooks LJ, Ward SD, Draper KA, Gozal D, Halbower AC, Jones J, Lehmann C, Schechter MS, Sheldon S, Shiffman RN, Spruyt K: Diagnosis and management of childhood obstructive sleep apnea syndrome. Pediatrics 2012, 130(3):e714-e755.

6. Benninger $\mathrm{M}$, Walner D: Obstructive sleep-disordered breathing in children. Clin Cornerstone 2007, 9(Suppl 1):S6-S12.
7. Witmans M, Young R: Update on pediatric sleep-disordered breathing. Pediatr Clin North Am 2011, 58(3):571-589.

8. Arens R, McDonough JM, Costarino AT, Mahboubi S, Tayag-Kier CE, Maislin G, Schwab RJ, Pack Al: Magnetic resonance imaging of the upper airway structure of children with obstructive sleep apnea syndrome. Am J Respir Crit Care Med 2001, 164(4):698-703.

9. Fregosi RF, Quan SF, Kaemingk KL, Morgan WJ, Goodwin JL, Cabrera R, Gmitro A: Sleep-disordered breathing, pharyngeal size and soft tissue anatomy in children. J Appl Physiol 2003, 95(5):2030-2038.

10. Isono S, Shimada A, Utsugi M, Konno A, Nishino T: Comparison of static mechanical properties of the passive pharynx between normal children and children with sleep-disordered breathing. Am J Respir Crit Care Med 1998, 157(4 Pt 1):1204-1212.

11. Cozza P, Polimeni A, Ballanti F: A modified monobloc for the treatment of obstructive sleep apnoea in paediatric patients. Eur J Orthod 2004, 26(5):523-530.

12. Kawashima S, Niikuni N, Chia-hung L, Takahasi Y, Kohno M, Nakajima I, Akasaka M, Sakata H, Akashi S: Cephalometric comparisons of craniofacial and upper airway structures in young children with obstructive sleep apnea syndrome. Ear Nose Throat J 2000, 79(7):499-502. 505-496.

13. Zettergren-Wijk L, Forsberg CM, Linder-Aronson S: Changes in dentofacial morphology after adeno-/tonsillectomy in young children with obstructive sleep apnoea-a 5-year follow-up study. Eur J Orthod 2006, 28(4):319-326

14. Deng J, Gao X: A case-control study of craniofacial features of children with obstructed sleep apnea. Sleep Breath 2012, 16(4):1219-1227.

15. Pirila-Parkkinen $K$, Pirttiniemi $P$, Nieminen $P$, Tolonen $U$, Pelttari $U$, Lopponen $H$ : Dental arch morphology in children with sleep-disordered breathing. Eur J Orthod 2009, 31(2):160-167.

16. Zucconi M, Caprioglio A, Calori G, Ferini-Strambi L, Oldani A, Castronovo C, Smirne S: Craniofacial modifications in children with habitual snoring and obstructive sleep apnoea: a case-control study. Eur Respir J 1999, 13(2):411-417.

17. Vieira BB, Itikawa $C E$, de Almeida LA, Sander HS, Fernandes RM, Anselmo-Lima WT, Valera FC: Cephalometric evaluation of facial pattern and hyoid bone position in children with obstructive sleep apnea syndrome. Int J Pediatr Otorhinolaryngol 2011, 75(3):383-386.

18. Vieira BB, Itikawa CE, de Almeida LA, Sander HH, Aragon DC, Anselmo-Lima WT, Matsumoto M, Valera FC: Facial features and hyoid bone position in preschool children with obstructive sleep apnea syndrome. Eur Arch Otorhinolaryngol 2014, 271(5):1305-1309

19. Pirila-Parkkinen $K$, Lopponen $H$, Nieminen $P$, Tolonen $U$, Pirttiniemi $P$. Cephalometric evaluation of children with nocturnal sleep-disordered breathing. Eur J Orthod 2010, 32(6):662-671.

20. Major MP, Flores-Mir C, Major PW: Assessment of lateral cephalometric diagnosis of adenoid hypertrophy and posterior upper airway obstruction: a systematic review. Am J Orthod Dentofacial Orthop 2006, 130(6):700-708.

21. Pirila-Parkkinen $K$, Lopponen $H$, Nieminen P, Tolonen U, Paakko E, Pirttiniemi P: Validity of upper airway assessment in children: a clinical, cephalometric, and MRI study. Angle Orthod 2011, 81(3):433-439.

22. Aboudara C, Nielsen I, Huang JC, Maki K, Miller AJ, Hatcher D: Comparison of airway space with conventional lateral headfilms and 3-dimensional reconstruction from cone-beam computed tomography. Am J Orthod Dentofacial Orthop 2009, 135(4):468-479.

23. McNamara JA Jr: A method of cephalometric evaluation. Am J Orthod 1984, 86(6):449-469.

24. Samman N, Mohammadi H, Xia J: Cephalometric norms for the upper airway in a healthy Hong Kong Chinese population. Hong Kong Med J 2003, 9(1):25-30.

25. Cooke MS, Wei SH: Cephalometric standards for the Southern Chinese Eur J Orthod 1988, 10(3):264-272.

26. Lundstrom A, Cooke MS: Proportional analysis of the facial profile in natural head position in Caucasian and Chinese children. Br J Orthod 1991, 18(1):43-49.

27. Hou HM, Sam K, Hagg U, Rabie AB, Bendeus M, Yam LY, Ip MS: Long-term dentofacial changes in Chinese obstructive sleep apnea patients after treatment with a mandibular advancement device. Angle Orthod 2006, 76(3):432-440.

28. Dahlberg G: Statistical Methods for Medical and Biological Students. London: Allen and Unwin; 1940 
29. Arens R, Marcus CL: Pathophysiology of upper airway obstruction: a developmental perspective. Sleep 2004, 27(5):997-1019.

30. Coccaro PJ, Coccaro PJ Jr: Dental development and the pharyngeal lymphoid tissue. Otolaryngol Clin North Am 1987, 20(2):241-257.

31. Battagel JM, Johal A, Kotecha B: A cephalometric comparison of subjects with snoring and obstructive sleep apnoea. Eur J Orthod 2000, 22(4):353-365.

32. Li AM, So HK, Au CT, Ho C, Lau J, Ng SK, Abdullah VJ, Fok TF, Wing YK: Epidemiology of obstructive sleep apnoea syndrome in Chinese children: a two-phase community study. Thorax 2010, 65(11):991-997.

33. Ursi WJ, Trotman CA, McNamara JA Jr, Behrents RG: Sexual dimorphism in normal craniofacial growth. Angle Orthod 1993, 63(1):47-56.

34. Sheng $C M$, $L$ in $L H$, Su Y, Tsai HH: Developmental changes in pharyngeal airway depth and hyoid bone position from childhood to young adulthood. Angle Orthod 2009, 79(3):484-490.

35. Li H, Lu X, Shi J, Shi H: Measurements of normal upper airway assessed by 3-dimensional computed tomography in Chinese children and adolescents. Int J Pediatr Otorhinolaryngol 2011, 75(10):1240-1246.

36. Taylor M, Hans MG, Strohl KP, Nelson S, Broadbent BH: Soft tissue growth of the oropharynx. Angle Orthod 1996, 66(5):393-400.

37. Mislik B, Hanggi MP, Signorelli L, Peltomaki TA, Patcas R: Pharyngeal airway dimensions: a cephalometric, growth-study-based analysis of physiological variations in children aged 6-17. Eur J Orthod 2014, 36(3):331-339.

38. Wu J, Hagg U, Rabie AB: Chinese norms of McNamara's cephalometric analysis. Angle Orthod 2007, 77(1):12-20.

39. Redline S, Tishler PV, Schluchter M, Aylor J, Clark K, Graham G: Risk factors for sleep-disordered breathing in children. Associations with obesity, race, and respiratory problems. Am J Respir Crit Care Med 1999, 159(5 Pt 1):1527-1532.

40. Khoo SM, Tan WC, Ng TP, Ho CH: Risk factors associated with habitual snoring and sleep-disordered breathing in a multi-ethnic Asian population: a population-based study. Respir Med 2004, 98(6):557-566.

41. Ozdemir H, Altin R, Sogut A, Cinar F, Mahmutyazicioglu K, Kart L, Uzun L, Davsanci H, Gundogdu S, Tomac N: Craniofacial differences according to AHI scores of children with obstructive sleep apnoea syndrome: cephalometric study in 39 patients. Pediatr Radiol 2004, 34(5):393-399.

42. Paal P, Niederklapfer T, Keller C, von Goedecke A, Luckner G, Pehboeck D, Mitterlechner T, Herff H, Riccabona U, Wenzel V: Head-position angles in children for opening the upper airway. Resuscitation 2010, 81(6):676-678.

43. Muto T, Takeda S, Kanazawa M, Yamazaki A, Fujiwara Y, Mizoguchi I: The effect of head posture on the pharyngeal airway space (PAS). Int J Oral Maxillofac Surg 2002, 31(6):579-583.

44. Ozbek MM, Miyamoto K, Lowe AA, Fleetham JA: Natural head posture, upper airway morphology and obstructive sleep apnoea severity in adults. Eur J Orthod 1998, 20(2):133-143.

\section{Submit your next manuscript to BioMed Central and take full advantage of:}

- Convenient online submission

- Thorough peer review

- No space constraints or color figure charges

- Immediate publication on acceptance

- Inclusion in PubMed, CAS, Scopus and Google Scholar

- Research which is freely available for redistribution 